\title{
PENYELENGGARAAN KETENTRAMAN DAN KETERTIBAN UMUM OLEH SATPOL PP DAN PENYIDIK PEGAWAI NEGERI SIPIL DI PROVINSI ACEH
}

\section{PEACE AND PUBLIC ORDER IMPLEMENTATION BY SATPOL PP AND CIVIL SERVANT INVESTIGATOR IN ACEH PROVINCE}

\author{
Gunawan \\ Pusat Penelitian Pemerintahan Umum dan Kependudukan \\ Badan Penelitian dan Pengembangan (BPP) Kementerian Dalam Negeri \\ Jl. Kramat Raya No. 132 - Senen, Jakarta \\ No. Telp./Faks: +62 21314 0454; HP. +62 81288140 777; +62 877888877866 \\ e-mail: gunplay18@yahoo.co.id, wawangunawan678@gmail.com \\ Diterima: 14 Mei 2012, Direvisi: 29 Mei 2012, Disetujui: 31 Mei 2012
}

\begin{abstract}
Abstrak
Kajian ini bertujuan untuk mengidentifikasi tugas dan fungsi Satuan Polisi Pamong Praja dalam penyelenggaraan ketentraman dan ketertiban umum. Lokasi kajian adalah Provinsi Aceh dengan metode kajian menggunakan pendekatan deskriptif kualitatif, dengan maksud untuk memperoleh gambaran yang nyata tentang pelaksanaan PPNS. Kajian menyimpulkan bahwa kelembagaan belum masuk dalam jabatan struktural, pembentukan sekretariat belum dilaksanakan, dan kualitas sumber daya manusianya belum optimal. Disarankan agar segera melakukan perubahan sistem jabatan struktural yang melekat pada PPNS diubah menjadi Jabatan Fungsional PPNS, membentuk Sekretariat PPNS pada Kantor Satpol PP, dan melakukan diklat bagi para pegawai.
\end{abstract}

Kata Kunci: Satpol PP, PPNS, ketentraman dan ketertiban.

\begin{abstract}
This study aims to identify the duties and functions of the Satpol PP in the implementation of peace and public order. What is the study of Aceh by the method of qualitative study used a descriptive approach, in order to obtain a real picture of the implementation of the PPNS. The study concluded that the institution has not been included in the structural position, the formation of the secretariat has not been implemented, and the quality of human resources is not optimal. It is recommended to immediately make changes to the system are attached to the structural position PPNS converted into functional investigators, established investigators in the office of the secretariat of the Satpol PP, and conduct training for employees.

Keywords: Satpol PP, PPNS, peace and order.
\end{abstract}

\section{PENDAHULUAN}

Undang-Undang Nomor 32 Tahun 2004 tentang Pemerintahan Daerah pada pasal 14 ayat (1) mengatur mengenai penyelenggaraan ketertiban umum dan ketenteraman masyarakat yang merupakan urusan wajib pemerintah daerah, dalam hal ini meliputi pemerintah provinsi, kabupaten dan kota, untuk kemudian dipertegas pada pasal 148 ayat (1) yang menyatakan bahwa untuk membantu kepala daerah dalam penegakan Peraturan Daerah (Perda) dan penyelenggaraan ketertiban umum dan ketenteraman masyarakat dapat dibentuk Satuan Polisi Pamong Praja (Satpol PP).

Satpol PP pada hakekatnya memberikan perlindungan kepada masyarakat, sehingga dapat terwujud rasa tenteram dan tertib di tengah-tengah masyarakat. Upaya menciptakan ketenteraman, ketertiban dan memberikan perlindungan kepada masyarakat tidak akan mudah dilaksanakan. Untuk itu, perlu adanya kelembagaan Satpol PP yang kuat dan tegas dalam melaksanakan tugas dan tanggung jawabnya.

Secara teknis, agar intruksi dalam UndangUndang Nomor 32 Tahun 2004 dapat diaplikasikan pada tataran pelaksanaan, maka dibuatlah aturan pelaksanaannya, berupa Peraturan Pemerintah Nomor 6 Tahun 2010 tentang Satuan Polisi Pamong Praja pada pasal 4, yang menjabarkan tugas pokok Satpol PP yakni menegakkan Perda dan menyelenggarakan ketertiban umum dan ketentraman masyarakat serta perlindungan masyarakat, dan pada pasal 5 dalam melaksanakan tugas sebagaimana dimaksud dalam pasal 4, Satpol PP mempunyai fungsi: (1) Menyusun program dan melaksanakan penegakan Perda, menyelenggarakan ketertiban umum dan ketenteraman masyarakat serta perlindungan masyarakat; (2) Melaksanakan kebijakan penegakan Perda dan peraturan kepala daerah; (3) Melaksanakan kebijakan penyelenggaraaan ketertiban umum dan ketenteraman masyarakat di daerah; (4) Melaksanakan kebijakan 
perlindungan masyarakat (5) Melaksanakan koordinasi penegakan Perda dan peraturan kepala daerah; menyelenggarakan ketertiban umum dan ketenteraman masyarakat dengan Kepolisian Negara Republik Indonesia, Penyidik Pegawai Negeri Sipil daerah, dan/atau aparatur lainnya, (6) Mengawasi masyarakat, aparatur, atau badan hukum agar mematuhi dan menaati Perda dan peraturan kepala daerah; dan (7) Melaksanakan tugas lainnya yang diberikan oleh kepala daerah.

Kementerian Dalam Negeri yang merupakan pembina Satpol PP di daerah, sebagaimana tertuang dalam PP Nomor 6 Tahun 2010 tersebut, pada pasal 30 ayat (1) menyebutkan bahwa Menteri Dalam Negeri melakukan pembinaan umum Satpol PP. Pembinaan yang dilakukan Menteri Dalam Negeri dalam melakukan pembinaan terhadap Satpol PP di daerah meliputi: fasilitasi, regulasi, monitoring dan evaluasi, dalam penjelasannya disebutkan bahwa pembinaan umum meliputi pemberian pedoman dan standar, bimbingan, supervisi, pendidikan dan pelatihan, monitoring dan evaluasi penyelenggaraan tugas Satpol PP; dan ayat (2) Gubernur, Bupati dan Walikota melakukan pembinaan teknis operasional Satpol PP, dalam penjelasannya disebutkan bahwa pembinaan teknis operasional, meliputi pembinaan kemampuan Satpol PP melalui pembinaan etika profesi, pengembangan pengetahuan dan pengalaman di bidang ke-pamong praja-an. Kementerian Dalam Negeri selaku pembina Satpol PP di daerah, dapat memberikan arahan dan kebijakan kepada kepala daerah untuk melaksanakan PP Nomor 6 Tahun 2010 dalam penjabarannya terdapat aturan dan ketentuan bagi Satpol PP dalam menyelenggarakan ketertiban dan ketentraman dalam kerangka perlindungan masyarakat, dibutuhkan koordinasi lintas instansi yang terkait perannya.

Peran Satpol PP yang tertuang dalam peraturan perundang-undangan merupakan peran yang tidak mudah dalam implementasinya butuh komitmen dan kesungguhan untuk dapat mewujudkannya dalam tugas pokok dan fungsinya. Berbagai upaya untuk meningkatkan profesionalisme dan kompetensi Polisi PP melalui peningkatan kemampuan aparat Polisi PP melalui berbagai kegiatan pendidikan dan pelatihan dengan bersinergi dengan pihak kepolisian, sehingga diharapkan kinerja dan pemahaman terhadap tugas pokok dan fungsi manjadi lebih jelas. Selanjutnya, terkait dengan perkembangan dan dinamika perubahan penyelenggaraan pemerintahan, tuntuntan terhadap Polisi PP untuk lebih dapat memahami isi setiap Perda turut serta mengimplementasikannya di lapangan, karena dapat dipastikan tugas Polisi PP akan bersentuhan langsung dengan masyarakat.

Sebagai perangkat pemerintah daerah, Satpol PP dalam menegakkan Perda dan menjaga ketertiban, serta ketenteraman, menurut PP Nomor 6 Tahun 2010 pasal 9 menyatakan pada ayat (1) bahwa bagi Polisi Pamong Praja yang memenuhi syarat dan dapat ditetapkan menjadi Penyidik Pegawai Negeri Sipil sesuai dengan ketentuan peraturan perundangundangan; dan ayat (2) Polisi Pamong Praja yang ditetapkan sebagai Penyidik Pegawai Negeri Sipil sebagaimana dimaksud pada ayat (1) dapat langsung mengadakan penyidikan terhadap pelanggaran Perda dan/atau peraturan kepala daerah yang dilakukan oleh warga masyarakat, aparatur atau badan hukum.

Selanjutnya, personel Satpol PP dalam melaksanakan penertiban umum dan ketenteraman masyarakat bertindak sebagai Penyidik Pegawai Negeri Sipil (PPNS) disamping tentunya pejabat lainnya yang ditunjuk, sesuai pasal 149 ayat (1) Satpol PP dapat diangkat sebagai Penyidik Pegawai Negeri Sipil sesuai dengan ketentuan peraturan perundang-undangan; ayat (2) Penyidikan dan penuntutan terhadap pelanggaran atas ketentuan Perda dilakukan oleh pejabat penyidik dan penuntut umum sesuai dengan peraturan perundang-undangan; dan ayat (3) Perda dapat juga ditunjuk pejabat lain yang diberi tugas untuk melakukan penyidikan terhadap pelanggaran atas ketentuan Perda. Makna pasal ini berarti bahwa yang dimaksud PPNS tersebut adalah personel Satpol PP dan/atau pejabat lainnya yang ditunjuk. Satpol PP dalam hal bertugas ganda sebagai pelaksana dan penyidik.

PPNS dalam melaksanakan tugas-tugasnya didasarkan dari laporan masyarakat maupun dari kelembagaan, dalam hal ini adalah kelembagaan/ institusi Satpol PP, berdasarkan surat edaran Kementerian Dalam Negeri Nomor 182.1/857/57/sj tanggal 18 Maret 2011 tentang Pembentukan Sekretariat PPNS di Satpol PP. Dalam melaksanakan tugasnya, Satpol PP bekerja berdasarkan peraturan dan kebijakan pemerintah daerah, di mana pemerintah daerah telah diberi kewenangan menyelenggarakan urusan pemerintahannya sebagaimana tertuang dalam Undang-Undang Nomor 32 Tahun 2004 pada pasal pasal 14 ayat (1) yang menyatakan bahwa urusan wajib yang menjadi kewenangan pemerintahan daerah untuk kabupaten/ kota merupakan urusan yang berskala kabupaten/ kota yang terdiri dari 16 urusan wajib dan atas dasar urusan wajib itulah, maka PPNS di daerah dikumpulkan dan disatukan dalam wadah sekretariat di Satpol PP, dengan harapan pelaksanaan tugas dan fungsi PPNS berjalan lebih cepat dan dapat terkoordinasi dengan baik, meskipun seringkali dalam pelaksanaan penyidikan suatu kasus, mengalami permasalahan dan kendala dengan pihak Kepolisian, Satpol PP dan PPNS itu sendiri.

Dari uraian di atas, dapat diidentifikasi permasalahan mengenai peran PPNS sebagai berikut: (1) Pembentukan Sekretariat PPNS pada Kantor Satpol PP di daerah belum dilaksanakan sesuai dengan Surat Kementerian Dalam Negeri (Kemendagri) Nomor 182.1/857/SJ Tahun 2011; (2) Sumber daya manusia yang tersedia sebagai PPNSD dalam menjalankan tugas dan fungsinya belum 
memenuhi harapan yang diinginkan berdasarkan kepada integritas, kompetensi, obyektifitas, dan independensi serta kualitas maupun kuantitas yang memadai; (3) Keterbatasan sarana \& prasarana PPNSD di Satpol PP belum mendukung dalam melaksanakan tugas dan fungsinya; dan d) Hubungan PPNSD dengan Satpol PP dan Penyidik Polri selaku pembina dan koordinator pengawas PPNSD dan Satpol PP belum konsisten.

Merujuk kepada hasil penelitian sebelumnya mengenai Studi Profil Satuan Polisi Pamong Praja, yang menunjukan bahwa masih banyak daerah yang belum memiliki PPNS, maka kajian ini lebih difokuskan pada identifikasi permasalahan yang menyebabkan peran dan eksistensi PPNS di daerah dalam pelaksanaan ketenteraman masyarakat dan ketertiban umum belum optimal. Kajian memilih lokasi di Provinsi Aceh dengan alasan bahwa provinsi tersebut memiliki keunikan tersendiri, yakni dari kekhususan yang diberikan oleh pemerintah untuk melaksanakan pemerintahan di daerah, yang berbeda dengan daerah lainnya di Indonesia.

\section{METODE PENELITIAN}

\section{Teknik Pendekatan}

Kajian ini menggunakan pendekatan penelitian kualitatif, dengan metode deskriptif, yang mana hal ini dimaksudkan untuk memberikan gambaran dan analisa yang lebih jelas mengenai peran tugas Penyidik Pegawai Negeri Sipil (PPNS) pada institusi Satpol PP. Pertimbangan ilmiah penggunaan jenis penelitian deskriptif, ialah untuk mendapatkan gambaran dan fenomena yang terjadi pada saat sekarang yang jelas terkait dengan faktafakta, gejala-gejala dari obyek kajian yang ditemukan di lapangan secara realistis-komprehensif.

Teknik pengumpulan data dilakukan dengan menggunakan sumber data primer dan data sekunder. Untuk memperoleh data yang diinginkan dalam kajian ini, digunakan teknik pengumpulan data berupa: (1) studi dokumentasi (documentation study), yaitu teknik pengumpulan data dengan mempelajari dokumen yang berkaitan dengan Satpol PP dengan tujuan untuk memperoleh data yang akurat dan dianggap perlu dalam melaksanakan kajian; (2) kuesioner (open and closed anded quistion), yaitu teknik pengumpulan data dengan membuat daftar pertanyaan yang berhubungan dengan fokus kajian ini. Daftar pertanyaan yang digunakan dibuat sedemikian rupa, sehingga responden dibatasi dalam memberikan jawaban pada beberapa alternatif, atau satu jawaban saja; dan (3) wawancara mendalam (in-depth interviews), yang dilakukan untuk membantu kekurangan dalam menganalis pada kusioner terbuka dan tertutup.

\section{Konsep Pemerintahan}

Pemerintah merupakan suatu gejala yang berlangsung dalam kehidupan bermasyarakat, yakni hubungan antara manusia dengan setiap kelompok termasuk dalam keluarga. Masyarakat sebagai suatu gabungan dari sistem sosial, akan senantiasa terkait dengan unsur-unsur pemenuhan kebutuhan dasar manusia seperti keselamatan, istirahat, pakaian dan makanan. Dalam memenuhi kebutuhan dasar tersebut, manusia perlu bekerja sama dan berkelompok dengan orang lain; dan bagi kebutuhan sekunder, maka diperlukan bahasa untuk berkomunikasi menurut makna yang disepakati bersama, dan institusi sosial yang berlaku sebagai kontrol dalam aktivitas dan mengembangkan masyarakat.

Kebutuhan sekunder tersebut adalah kebutuhan untuk bekerjasama, menyelesaikan konflik, dan interaksi antar sesama warga masyarakat. Dengan timbulnya kebutuhan dasar dan sekunder tersebut, maka terbentuk pula institusi sosial yang dapat memberi pedoman melakukan kontrol dan mempersatukan (integrasi) anggota masyarakat (Malinowski dalam Garna, 2000). Untuk membentuk institusi-institusi tersebut, masyarakat membuat kesepakatan atau perjanjian di antara mereka, yang menurut Rosseau (terjemahan Sumardjo, 1986) adalah konflik kontrak sosial (social contract). Adanya kontrak sosial tersebut selanjutnya melahirkan kekuasan dan institusi pemerintahan.

Lahirnya pemerintahan pada awalnya adalah untuk menjaga suatu sistem ketertiban di dalam masyarakat, sehingga masyarakat tersebut bisa menjalankan kehidupan secara wajar. Seiring dengan perkembangan masyarakat modern yang ditandai dengan meningkatnya kebutuhan, peran pemerintah kemudian berubah menjadi pelayan masyarakat. Pemerintah modern, dengan kata lain pada hakekatnya adalah pelayanan kepada masyarakat. Pemerintah tidaklah diadakan untuk melayani diri sendiri, tetapi untuk melayani masyarakat, menciptakan kondisi yang memungkinkan setiap anggota mengembangkan kemampuan dan kreatifitasnya demi mencapai kemajuan bersama (Rasyid, 2000). Osborne dan Gaebler (terjemahan Rasyid, 2000), bahkan menyatakan bahwa pemerintah yang demokratis lahir untuk melayani warganya dan karena itulah tugas pemerintah adalah mencari cara untuk menyenangkan warganya.

Dengan demikian lahirnya pemerintahan memberikan pemahaman bahwa kehadiran suatu pemerintahan merupakan manifestasi dari kehendak masyarakat yang bertujuan untuk berbuat baik bagi kepentingan masyarakat, bahkan Van Poelje (dalam Hamdi, 1999) menegaskan bahwa pemerintahan dapat dipandang sebagai suatu ilmu, yaitu yang mengajarkan bagaimana cara terbaik dalam mengarahkan dan memimpin pelayanan umum. Defenisi ini menggambarkan bahwa pemerintahan sebagai suatu ilmu mencakup 2 (dua) unsur utama, yaitu: pertama; masalah bagaimana sebaiknya pelayanan umum dikelola, jadi termasuk seluruh 
permasalahan pelayanan umum, dilihat dan dimengerti dari sudut kemanusiaan; kedua, masalah bagaimana sebaiknya

Menurut Inu Kencana Syafiie (1998), secara etimologis kata pemerintahan berasal dari kata:

1. Perintah berarti melakukan pekerjaan menyuruh. Yang berarti di dalamnya terdapat dua pihak, yaitu yang merintah memiliki wewenang dan yang diperintah memiliki kepatuhan dan keharusan.

2. Setelah ditambah awalan pe menjadi pemerintah, yang berarti badan yang melakukan kekuasaan memerintah.

3. Setelah di tambah lagi akhiran an menjadi pemerintahan, yang berarti perbuatan, cara, hal atau urusan dari badan yang memerintah tersebut.

Pemerintah adalah gejala sosial, artinya di dalam hubungan antar anggota masyarakat, baik individu dengan individu dan kelompok maupun antar individu dengan kelompok. (Ndraha, 1997). Menurut R. Mac.Iver (dalam Syafiie, 2002) pengertian pemerintahan adalah: "Suatu organisasi dari orang-orang yang mempunyai kekuasaan. Bagaimana manusia itu bisa diperintah”.

Secara etimologis kata pemerintahan berasal dari kata pemerintahan, kata pemerintah sendiri berasal dari kata Perintah yang berarti menyuruh melakukan suatu pekerjaan (Pamudji, 1985). Namun tinjauan asal kata pemerintah sebenarnya berasal dari kata dalam bahasa Inggris "government" yang diterjemahkan sebagai pemerintah dan pemerintahan dalam banyak tulisan. Namun, ada juga yang berpendapat bahwa "government" tidak selalu memiliki makna pemerintahan, karena Samuel Edward Finer mengartikan "government" sebagai public servant, yakni pelayanan. Sehingga Samuel Edward Finer (dalam Syafiie, 2002) menyimpulkan bahwa kata government dapat memiliki arti:

a. Menunjuk kepada kegiatan atau proses pemerintah, yakni melakukan kontrol atas pihak lain;

b. Menunjuk pada masalah-masalah Negara dalam kegiatan atau proses dijumpai;

c. Menunjukan cara, metode, atau sistem dengan masa suatu masyarakat tertentu diperintah.

Berdasarkan uraian diatas dapat disimpulkan bahwa pemerintahan merupakan lembaga atau badan yang mempunyai wewenang (kekuasaan) untuk memerintah dan mengatur urusan negaranya berdasarkan sistem yang dianutnya.

\section{Konsep Penyidik Pegawai Negeri Sipil}

Dalam Undang-Undang Nomor 8 Tahun 1981 tentang Kitab Undang-Undang Hukum Acara Pidana pada pasal 1 angka 1 dan pasal 6 ayat (1) menyebutkan bahwa ada dua pejabat yang berkedudukan sebagai penyidik, yaitu pejabat polisi negara Republik Indonesia dan pejabat pegawai negeri sipil. Selanjutnya, dalam PP Nomor 58 Tahun 2010 tentang Perubahan Atas PP Nomor 27 Tahun 1983 tentang Pelaksanaan Kitab Undang-Undang Hukum Acara Pidana, yang merupakan peraturan pelaksanaan undang-undang tersebut di atas, disebutkan bahwa Pejabat Penyidik Pegawai Negeri Sipil yang selanjutnya disebut pejabat PPNS adalah pegawai negeri sipil tertentu, sebagaimana dimaksud dalam KUHAP, baik yang berada di pusat maupun daerah, yang diberi wewenang khusus oleh undangundang. Kemudian, pada pasal 2 PP Nomor 58 Tahun 2010 tersebut, penyidik adalah, pertama: penyidik adalah pejabat Kepolisian Negara Republik Indonesia; dan kedua, penyidik adalah pejabat pegawai negeri sipil yang bertugas melaksanakan menyelenggarakan penegakan supremasi hukum dengan berprilaku sebagai pelindung dan pelayan masyarakat yang harus dipertanggung jawabkan menurut norma hukum, norma agama, norma moral, dan norma sosial.

Adapun PPNS menurut Peraturan Kepala Kepolisian Negara Republik Indonesia Nomor 6 Tahun 2010 tentang Manajemen Penyidikan Oleh Penyidik Pegawai Negeri Sipil, adalah Pejabat Pegawai Negeri Sipil tertentu yang diberi wewenang khusus oleh undang-undang untuk melakukan penyidikan tindak pidana sesuai undang-undang yang menjadi dasar hukumnya masing-masing, dan dalam pelaksanaan tugasnya berada di bawah koordinasi dan pengawasan Penyidik Polri. Dengan demikian, menjadi jelas bahwa PPNS dibawah koordinasi dan pengawasan Kepolisian Republik Indonesia. Selanjutnya, juga dijelaskan pada Peraturan Menteri Dalam Negeri Nomor 11 Tahun 2009 tentang Kode Etik Penyidik Pegawai Negeri Sipil Daerah, mengenai keberadaan PPNSD menyebutkannya sebagai Pegawai Negeri pejabat Pegawai Negeri Sipil tertentu di lingkungan pemerintah daerah yang diberi wewenang khusus oleh Undang-Undang untuk melakukan penyidikan terhadap pelanggaran Perda.

PPNSD dalam melaksanakan tugas dan tanggungjawabnya, berpedoman pada Peraturan Menteri Dalam Negeri Nomor 11 Tahun 2009, dengan memiliki karakteristik pada kode etik profesi PPNSD, yaitu norma yang digunakan sebagai pedoman yang harus ditaati oleh PPNSD dalam melaksanakan tugasnya agar sesuai dengan prosedur penyidikan, ketentuan peraturan perundangundangan, dan Perda. PPNSD harus menjunjung tinggi hak asasi manusia serta prinsip-prinsip yang mendasarinya, yaitu integritas, memiliki kepribadian yang dilandasi oleh unsur jujur, berani, bijaksana dan bertanggungjawab; kompetensi, yakni memiliki pengetahuan, keahlian, pengalaman, dan keterampilan yang diperlukan dalam melaksanakan tugasnya; obyektifitas, yakni menjunjung tinggi ketidakperpihakan dalam melaksanakan tugasnya; 
dan independensi, yakni tidak terpengaruh terhadap adanya tekanan atau kepentingan pihak manapun.

Menurut Herujito (2001), mengenai pengawasan yang dilakukan PPNS, pengawasan pengawasan dapat ditinjau dari tiga aspek, yaitu: (1) Waktu: yang dimaksud pengawasan dari segi waktu dapat dilakukan secara preventif dan secara refresif, alat yang dipakai untuk pengawasan ialah perencanaan dan budget, sedangkan pengawasan secara refresif menggunakan alat budget dan laporan; (2) Objek: ialah pengawasan terhadap produksi, keuangan, aktivitas karyawan dan sebagainya ada juga yang menyatakan pengawasan dari segi objek merupakan pengawasan administratif dan pengawasan operatif, contoh pengawasan administratif ialah pengawasan anggaran, inspeksi dan pengawasan order (standing order) dan pengawasan kebijaksanaan (policies controling); dan (3) Subjek: terdiri dari pengawasan intern dan ekstern. Adapun pengawasan yang dilakukan oleh Kepolisian terhadap PPNS adalah pengawasan subjek ekstern, sedangkan pengawasan yang dilakukan PPNS adalah menegakan perda, yang merupakan pengawasan kebijaksanaan, yang termasuk dalam pengawasan objek.

Sebagai unsur pengawasan dan memberikan fasilitasi koordinatif bagi PPNS, tentunya Kepolisian Republik Indonesia mempunyai mekanisme dan aturan jalannya pelaksanaan tugas dan pokok PPNS sebagaimana disebut pada bab II Pengawasan, Pengamatan dan Penelitian serta pemeriksaan pasal 5 yang menyebutkan pengawasan, pengamatan, penelitian atau pemeriksaan ayat (1) dilaksanakan atas dasar: (a) hasil temuan dari petugas; dan/atau dan (b) laporan/pengaduan masyarakat, yang dapat diajukan secara tertulis maupun lisan. (2) terhadap laporan/pengaduan masyarakat sebagaimana dimaksud pada ayat (1) huruf $b$, kepada pelapor diberikan surat tanda penerimaan laporan. (3) hasil pengawasan, pengamatan, penelitian atau pemeriksaan sebagaimana dimaksud pada ayat (1), apabila ditemukan tindak pidana, dituangkan dalam laporan kejadian.

Seperti telah dikemukakan di atas, bahwa tindakan yang dilakukan PPNS pada Unit Satpol PP adalah tindakan lanjutan yang dilakukan oleh Satpol PP dalam bentuk laporan hasil temuan petugas ketika melaksanakan dan menyelenggarakan ketertiban umum, ketenteraman masyarakat serta perlindungan terhadap masyarakat, yang selanjutnya dijelaskan kembali pada pasal 6 yang berisikan bahwa: (1) Laporan kejadian sebagaimana dimaksud dalam Pasal 5 ayat (3) dilaporkan kepada atasan PPNS dan dicatat dalam registrasi penerimaan laporan kejadian. (2) Laporan kejadian sebagaimana dimaksud dalam Pasal 5 ayat (3), berisikan uraian singkat mengenai peristiwa yang terjadi atau dugaan terjadinya pelanggaran pidana. (3) Atasan PPNS setelah menerima laporan kejadian sebagaimana dimaksud pada ayat (1), menerbitkan surat perintah penyidikan dan memberi petunjuk mengenai pelaksanaan penyidikan.

Atasan langsung PPNS pada Unit Satuan Polisi Pamong Praja adalah Kepala Satuan Polisi Pamong Praja (Kasatpol PP), sesuai dengan amanat Peraturan Kepala Kepolisian Negara Republik Indonesia Nomor 6 Tahun 2010, menyebutkan bahwa yang menjadi atasan PPNS adalah PPNS atau Pimpinan pada instansi. Ketika dalam melakukan penyidikan, seorang Pejabat PPNS dapat meminta bantuan terahadap penyidik Kepolisian sebagaimana tertuang dalam Keputusan Kepala Kepolisian Negara Republik Indonesia Nomor 6 Tahun 2010 pada pasal 8 ayat 2 menjelaskan bahwa dalam pelaksanaan pengamanan, penanganan, dan pengolahan TKP sebagaimana dimaksud pada ayat (1), disesuaikan dengan karakter dan bidang tugas PPNS masing-masing. (3) Dalam hal pelaksanaan kegiatan sebagaimana dimaksud pada ayat (1) membutuhkan tindakan taktis dan teknis di TKP, PPNS dapat meminta bantuan kepada Penyidik Polri.

PP Nomor 58 Tahun 2010 tentang Pelaksanaan Kitab Undang-Undang Hukum Acara Pidana Pejabat Penyidik Pegawai Negeri Sipil, menyebutkan bahwa calon Penyidik harus memenuhi persyaratan Pengangkatan PPNS, yakni masa kerja sebagai pegawai negeri sipil paling singkat 2 (dua) tahun; berpangkat paling rendah Penata Muda/golongan III/a; berpendidikan paling rendah sarjana hokum atau sarjana lain yang setara; bertugas di bidang teknis operasional penegakan hukum; sehat jasmani dan rohani yang dibuktikan dengan surat keterangan dokter pada rumah sakit pemerintah; setiap unsur penilaian pelaksanaan pekerjaan dalam Daftar Penilaian Pelaksanaan Pekerjaan (DP3) pegawai negeri sipil paling sedikit bernilai baik dalam 2 (dua) tahun terakhir; dan mengikuti dan lulus pendidikan dan pelatihan di bidang penyidikan; harus mempunyai moral baik, integritas, dedikasi dan professional; menyesuaikan jumlah personel PPNS dengan beban tugas yang dihadapi; mempunyai pola kerja sama antar PPNS dalam pelaksanaan penyidikan; membentuk team supervisi atau asistensi yang dapat mengawasi proses penyidikan; dan menghindari hubungan subjektivitas antara PPNS dengan tersangka.

Tugas Kepolisian Negara Republik Indonesia dalam menjaga ketenteraman, ketertiban dan perlindungan masyarakat dan juga merupakan tugas Satuan Polisi Pamong Praja, yaitu terdapat pada tugas pokok Kepolisian Negara Republik Indonesia dalam Undang-Undang Nomor 2 Tahun 2002 tentang Kepolisian Negara Republik Indonesia, pada Bab III Pasal 13 mengenai Tugas Pokok Kepolisian Negara Republik Indonesia adalah memelihara keamanan dan ketertiban masyarakat, menegakan hukum dan memberikan perlindungan, pengayoman, dan pelayanan kepada masyarakat.

Keberadaan PPNS pada unit Satpol PP merupakan elemen pendukung utama dalam 
Tabel 1. Komposisi PPNS di Satpol PP Provinsi NAD

\begin{tabular}{clcccc}
\hline \multirow{2}{*}{ No. } & \multirow{2}{*}{ Provinsi/Kabupaten/Kota } & \multicolumn{4}{c}{ SDM Satpol PP } \\
\cline { 3 - 6 } & & Pol PP & WH & PPNS & Jumlah \\
\hline 1. & Provinsi NAD & 71 & 14 & 14 & 99 \\
2. & Kota Sabang & 135 & 27 & 1 & 163 \\
3. & Kabupaten Aceh Besar & 73 & 39 & 5 & 117 \\
\hline \multicolumn{2}{l}{ Sumber: Satpol PP Prov.NAD, 2012. } & \multicolumn{4}{c}{}
\end{tabular}

Tabel 2. Luas Wilayah, Jumlah Penduduk dan Jumlah Kecamatan Lokasi Penelitian

\begin{tabular}{llrrr}
\hline \multirow{2}{*}{ No. } & Provinsi/Kabupaten/Kota & \multicolumn{3}{c}{ Komposisi } \\
\cline { 3 - 5 } & & $\begin{array}{c}\text { Luas Wilayah } \\
\left(\mathbf{k m}^{\mathbf{2}}\right)\end{array}$ & $\begin{array}{c}\text { Penduduk } \\
(\mathbf{j i w a})\end{array}$ & Kecamatan \\
\hline 1. & Provinsi NAD & 57.956 & 4.948 .907 & 286 \\
2. & Kota Sabang & 153 & 35.600 & 2 \\
3. & Kabupaten Aceh Besar & 2.969 & 366.612 & 23 \\
\hline Sumber: & BPS, Prov NAD dalam Angka, 2011. & &
\end{tabular}

Sumber: BPS, Prov.NAD dalam Angka, 2011.

melaksanakan tugas lanjutan yang diperlukan dalam penanganan kepada lembaga peradilan, menurut Keputusan Kepala Kepolisian Negera Republik Nomor 6 Tahun 2010 pada pasal 13 mengenai Pengorganisasi PPNS pada ayat 1, bahwa dalam pelaksanaan penyidikan oleh PPNS, diperlukan pengorganisasian sumber daya yang meliputi: (1) personel PPNS; (2) sarana dan pra sarana; (3) anggaran; dan (4) peraturan maupun piranti lunak. Pelaksanaan pengorganisasian sumber daya sebagaimana dapat dilaksanakan oleh atasan PPNS berdasarkan hubungan dan tata kerja organisasi di lingkungan instansi PPNS. Sumber daya inilah yang nantinya akan menentukan kinerja dari PPNS pada instansi Satpol PP dalam menindaklanjuti laporan yang diberikan oleh Satpol PP ketika melaksanakan dan menyelenggarakan ketertiban umum, ketenteraman masyarakat serta perlindungan masyarakat.

Pejabat PPNS dalam melaksanakan tugas dan menangani serta menuntaskan kasus per kasus PPNS dapat melakukan secara berkelompok antara 2 (dua) sampai dengan 5 (lima) PPNS yang diatur dalam Keputusan Kepala Kepolisian Negera Republik Nomor 6 Tahun 2010 pada pasal 15, yaitu pengorganisasian personel PPNS dapat digolongkan sebagai berikut: (1) Pada kasus yang mudah, dapat dilaksanakan oleh 2 (dua) PPNS; (2) Pada kasus yang sedang, dapat dilaksanakan oleh 3 (tiga) PPNS; (3) Pada kasus yang sulit, dapat dilaksanakan oleh 4 (empat) PPNS; (4) Pada kasus yang sangat sulit, dilaksanakan oleh tim yang beranggotakan paling sedikit 5 (lima) PPNS.

\section{HASIL DAN PEMBAHASAN}

Berdasarkan data lapangan, jumlah sumber daya manusia aparatur Satuan Polisi Pamong Praja dan Wilayatul Hisbah Provinsi Aceh Darussalam dapat dilihat pada Tabel 1 berikut ini:
Dari komposisi di atas, terlihat bahwa jumlah terbesar PPNS di Provinsi Aceh berasal dari Polisi PP, sedangkan Wilayatul Hisbah dan PPNS sendiri sama-sama sebanyak 14 personel. Komposisi yang berbeda terjadi di Kota Sabang, di mana jumlah personel PPNS keseluruhan adalah sebanyak 163 personel, yang terdiri dari unsur Polisi PP 135 personel, Wilayatul Hisbah 27 personel, dan unsur PPNS hanya 1 personel saja, itupun sebenarnya berasal dari unit Satpol Wilyatul Hisbah. Sedangkan jumlah PPNS di Kabupaten Aceh Besar adalah sebanyak 117 personel, dengan komposisi dari Polisi PP sebanyak 73 personel, Wilayatul Hisbah 39 personel, dan PPNS 5 personel. Dari jumlah keseluruhan PPNS yang ada apabila dibandingkan dengan jumlah penduduk yang ada pada wilayah masing-masing, maka keberadaan PPNS dapat dikatagorikan belum proporsonal, sehingga masih diperlukan penambahan anggota personel, baik di unsur Satpol PP, unsur Satpol Wilyatul Hisbah maupun pada unsur PPNS. Adapun luas wilayah dan jumlah penduduk yang dilayani oleh Satpol PP dapat dilihat pada Tabel 2 .

Dari data terlihat bahwa ratio perbanding jumlah antara luas wilayah dan jumlah penduduk yang dilayani oleh PPNS di Provinsi Aceh adalah 1 melayani $585,41 \mathrm{~km}^{2}$ dan 49.989 orang masyarakat. Di Kabupaten Aceh Besar 1 orang PPNS melayani $25,38 \mathrm{~km}^{2}$ dan 3.133 orang masyarakat, sedangkan di Kota Sabang jauh lebih ideal, yakni 1 orang PPNS melayani $0,94 \mathrm{~km}^{2}$ dan 218 orang masyarakat.

Dari komposisi jenis kelamin dan usia pada Tabel 3 dan Tabel 4, terlihat bahwa PPNS di Provinsi Aceh, Kota Sabang dan Kabupaten Aceh Besar, di dapat data bahwa sebagian besar PPNS berjenis kelamin pria dengan usia yang terbesar pada golongan 36-45 tahun. Dari komposisi tersebut, dapat disimpulkan bahwa PPNS di Provinsi Aceh, Kota Sabang dan Kabupaten Aceh Besar lebih bagus bila dibandingkan dengan daerah-daerah lain yang 
Tabel 3. Komposisi PPNS Provinsi NAD Berdasarkan Jenis Kelamin

\begin{tabular}{clcc}
\hline \multirow{2}{*}{ No. } & \multirow{2}{*}{ Provinsi/Kabupaten/Kota } & \multicolumn{2}{c}{ Jenis Kelamin } \\
& & Pria & Wanita \\
\cline { 3 - 4 } & & 11 & 3 \\
\hline 1. & Provinsi NAD & 1 & 0 \\
2. & Kota Sabang & 4 & 1 \\
3. & Kabupaten Aceh Besar & \multicolumn{2}{c}{}
\end{tabular}

Tabel 4. Komposisi PPNS Provinsi NAD Berdasarkan Usia

\begin{tabular}{clccccc}
\hline \multirow{2}{*}{ No. } & \multirow{2}{*}{ Provinsi/Kabupaten/Kota } & \multicolumn{5}{c}{ Usia PPNS } \\
\cline { 3 - 7 } & & $<\mathbf{2 5}$ & $\mathbf{2 6 - 3 5}$ & $\mathbf{3 6 - 4 5}$ & $\mathbf{4 6 - 5 5}$ & $>\mathbf{5 6}$ \\
\hline 1. & Provinsi NAD & 0 & 4 & 6 & 2 & 2 \\
2. & Kota Sabang & 0 & 0 & 1 & 0 & 0 \\
3. & Kabupaten Aceh Besar & 0 & 0 & 3 & 2 & 0 \\
\hline
\end{tabular}

Sumber: Satpol PP Prov.NAD, 2012.

Tabel 5. Komposisi PPNS Provinsi NAD Berdasarkan Tingkat Pendidikan

\begin{tabular}{clcccc}
\hline \multirow{2}{*}{ No. } & \multirow{2}{*}{ Provinsi/Kabupaten/Kota } & \multicolumn{4}{c}{ Tingkat Pendidikan PPNS } \\
\cline { 3 - 6 } & & SLTA & S-1 & S-2 & S-3 \\
\hline 1. & Provinsi NAD & 0 & 13 & 1 & 0 \\
2. & Kota Sabang & 0 & 1 & 0 & 0 \\
3. & Kabupaten Aceh Besar & 2 & 3 & 0 & 0 \\
\hline
\end{tabular}

Sumber: Satpol PP Prov.NAD, 2012.

kesemuanya berjenis kelamin pria dan tidak memiliki PPNS berjenis kelamin wanita. Dengan adanya PPNS berjenis kelamin wanita, diharapkan akan mengurangi efek negatif yang akan timbul di masa yang akan datang, seperti ketika melakukan pemeriksaan terhadap kaum hawa untuk menghindari pelecehan seksual, maka yang memeriksa harus dilakukan oleh perempuan. Adapun untuk usia, PPNS di Provinsi Aceh, Kota Sabang dan Kabupaten Aceh Besar harus segera melakukan regenerasi, mengingat sebagian besar PPNS yang ada sekarang akan memasuki usia pensiun.

Dari Tabel 5 di atas, dapat dilihat tingkatan pendidikan PPNS yang ada di Provinsi Aceh, Kota Sabang dan Kabupaten Aceh Besar, maka terlihat bahwa sebagian besar berada tingkat pendidikan sarjana strata-1 (S-1), sedangkan yang berpendidikan pasca sarjana, yakni tingkat strata-2 (S-2) baru ada satu orang, yang terdapat pada Satpol PP Provinsi Aceh. Fakta tersebut menunjukan, bahwa yang menjadi PPNS di Provinsi Aceh, Kota Sabang dan Kabupaten Aceh Besar sesuai dengan PP Nomor 58 Tahun 2010 telah terpenuhi, yaitu persyaratan untuk menjadi PPNS adalah paling rendah berpendidikan sarjana atau sederajat, meskipun dalam pelaksanaannya, personel PPNS yang ada sebagian besar dibiayai dari dana Badan Rehabilitasi dan Rekonstruksi (BRR) Aceh.

Seperti diketahui bahwa Provinsi Aceh mempunyai dua peraturan, yaitu peraturan yang mengatur secara keseluruhan pada wilayah, baik di provinsi, kabupaten dan kota dalam bentuk Perda, Pergub, Perbup, dan Perwali dan Qanun, yaitu suatu aturan atau perintah yang mengatur khusus dalam mendirikan atau menjalankan syariat Islam dalam bentuk Qanun. Adapun Qanun-Qanun tersebut mengatur antara lain, Qanun 10 Tahun 2002 tentang Peradilan Syariat Islam, Pelaksanaan Ibadah Syariat Islam Bidang Aqidah, Ibadah dan Syiar Islam diatur dalam Qanon 11 Tahun 2002, kemudian Qanon 12 Tahun 2003 tentang Minuman Khamer dan sejenisnya, Qanon 13 Tahun 2003 tentang Maisir (perjudian), Qanon 14 Tahun 2004 tentang Khalwat (mesum), dan Qanun 7 Tahun 2004 tentang Pengelolaan Zakat.

Berdasarkan PP Nomor 6 Tahun 2010, keberadaan Satpol PP dan PPNS dalam regulasi sudah jelas dan tidak diperdebatkan lagi, namun yang masih menjadi ganjalan adalah keberadaan Wilayatul Hisbah di dalam organisasi Satpol PP, belum diatur secara implisit. Meskipun Wilayatul Hisbah ini sudah ada dan terbentuk di dalam susunan organisasi Satpol WH, di mana untuk sementara sambil menunggu peraturan yang baru, baik dari pemerintah provinsi maupun dari pemerintah kabupaten/kota, berada pada koordinasi dan dirangkap oleh Kepala Satpol PP. Rencana kedepan, Organisasi Satpol PP dan Wilayatul Hisbah ini akan dibedakan menurut tupoksi masing-masing, di mana tugas pokok Satpol PP berada pada area pengawasan dan menjaga Perda, sedangkan Satpol WH mengawasi dan menjaga Qanun. Dalam pelaksanaan 
di lapangan, kedua unsur ini dapat saja bekerjasama ketika Polisi PP melakukan operasi, dapat meminta bantuan Polisi WH dan begitu juga sebaliknya Polisi WH dapat meminta bantuan Polisi PP dalam melakukan operasi Syariat Islam. Wilayatul Hisbah sebelum disatukan dengan Polisi PP dan berada pada organisasi Dinas Syariat Islam, namun karena tugas Polisi WH dengan tugas Pol PP kadang berhimpitan dan ada kemiripan, maka Polisi WH untuk sementara di gabungkan ke Polisi PP, meskipun nantinya Polisi WH akan diarahkan untuk berdiri sendiri.

Pasca tsunami pada tahun 2003, Pemerintah Provinsi Aceh melakukan pendidikan dan pelatihan bagi personel PPNS, di mana tujuan utama adalah memperkuat personel PPNS, terutama personel Wilayatul Hisbah. Pendidikan dan pelatihan PPNS itu dibiayai oleh Badan Rekonstruksi dan Rehabilitasi (BRR), meskipun sampai sekarang belum keluar Surat Keputusan dan Ketetapan (SKEP) dan Kartu Tanda Penyidik (KTP), sehingga personel calon PPNS yang telah mengikuti pendidikan dan pelatihan tersebut diperlukan belum dapat melaksanakan tugas sebagai PPNS.

Kepolisian Daerah (Polda) Aceh Resort Sabang mengidentifikasi instansi yang memiliki PPNS, dan hasilnya terdapat 13 instansi/dinas yang ada PPNSnya, dengan jumlah personel ada 14 PPNS pada Dinas Perindustrian dan Perdagangan, Dinas Pertanian dan Kehutanan, Kantor Satpol PP, Kantor Imigrasi kelas II, Dinas Perhubungan Kota dan Kantor Pelayanan Bea Cukai di Kota Sabang, di mana masing-masing terdapat satu orang PPNS. Sedangkan pada Dinas Syariat Islam dan Dinas Kelautan dan Perikanan Kota Sabang masing-masing memiliki 3 orang PPNS, serta pada Dinas Perhubungan Laut/Navigasi teradapat 2 orang PPNS. Adapun pada Dinas Badan Karantina, Dinas Tenaga Kerja, Kependudukan \& Catatan Sipil, Dinas Informasi dan Komunikasi dan Dinas Kesehatan tidak memiliki PPNS.

Dari data yang diperoleh dari Pemerintah Daerah Provinsi Aceh, Pemerintah Kota Sabang dan
Pemerintah Daerah Aceh Besar, hasil penyidikan yang dilakukan PPNS pada tahun 2011 terdapat penyidikan yang bersifat teguran dan pembinaan, khususnya yang berkaitan dengan penegakan Qanun sebanyak 813 kasus. Berdasarkan kinerja PPNS pada Satpol PP dan Wilayatul Hisbah (WH) di Provinsi Aceh pada tahun 2011, beberapa perkara yang sudah diproses dan dilakukan pembinaan adalah sebagai berikut: Qanun 10 Tahun 2002 tentang Peradilan Syariat Islam 2 kasus, pelaksanaan ibadah Syariat Islam Bidang Aqidah 1 kasus, Qanon 11 Tahun 2002 tentang Ibadah dan Syiar Islam sebanyak 321 kasus, Qanon 12 Tahun 2003 tentang Minuman Khamer dan sejenisnya sebanyak 12 Kasus, Qanon 13 Tahun 2003 tentang Maisir (perjudian) 3 kasus, Qanon 14 Tahun 2004 tentang Khalwat (mesum) 163 kasus, Qanun 7 Tahun 2004 tentang Pengelolaan Zakat 1 kasus, Perda Nomor 5 Tahun 2000 untuk Anak Punk sebanyak 85 kasus, sedangkan untuk waria sebanyak 27 kasus. Adapun keberadaan Gepeng sebanyak 34 kasus, PP Nomor 53 Tahun 2010 tentang Disiplin PNS sebanyak 58 kasus, Pergub Nomor 47 Tahun 2007 tentang Disiplin Sekolah sebanyak 110 kasus.

Dari semua perkara yang diproses tersebut, penyelesaiannya masih bersifat pembinaan yang dilakukan di kantor yakni sebanyak 438 kasus, sedangkan pembinaan di tempat terdapat 44 kasus, dan penyelesaian melalui adat, tahap jaksa/P21, putusan hakim masih kosong/belum ada yang ditindak lanjutinya, melainkan hanya sebatas pada pembinaan.

Untuk lebih jelasnya, angka penyelesaian kasus pada periode 2009 sampai dengan 2011, dapat dilihat pada Gambar 1 dibawah.

Di satu sisi, faktanya masyarakat di Provinsi Aceh telah mengetahui keberadaan Satpol PP dengan atribut yang dikenakannya, dan Satpol PP ketika melakukan penertiban di pasar-pasar dan di jalanjalan, baik itu yang diketahuinya dari media elektronik maupun media surat kabar, begitu juga dengan Wilayatul Hisbah, di mana masyarakat mengetahui Wilayatul Hisbah merupakan polisi

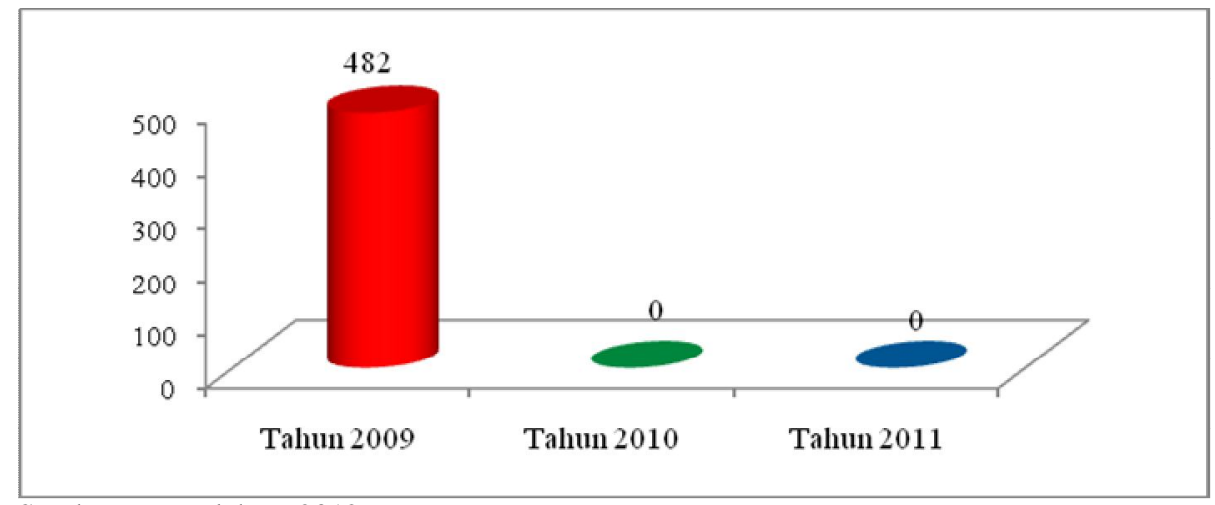

Sumber: Data olahan, 2012.

Gambar 1. Rekapitulasi Kasus yang Diselesaikan oleh Satpol PP dan WH Tahun 2009 s/d 2011. 
dengan tujuan mendirikan dan menegakan Syariat Islam, yang fungsinya hampir sama dengan Satpol PP. Di sisi lainnya, untuk memahami dan mengetahui kewenangan PPNS, sebagian besar masyarakat di Provinsi Aceh belum mengetahuinya secara utuh. Hanya sebagian kecil yang mengetahui keberadaan PPNS, dan itupun diketahui dari atributi yang digunakan berupa pakaian coklat, di mana tugasnya menangkap dan menggeledah masyarakat. Hal itu berarti, bahwa masyarakat terindikasi mengetahui PPNS yang dimaksud bukan PPNS Satpol PP dan Wilayatul Hisbah. Fakta lainnya, bahwa beberapa personel PPNS tidak memberikan contoh positif kepada masyarakat. Masyarakat hampir tidak mengetahui pekerjaan dari oknum PPNS, di mana hanya datang pagi untuk absen, kemudian pergi keluar kantor dan pada sore harinya baru kembali lagi ke kantor untuk absen pulang. Artinya, di mata masyarakat, PPNS dari Satpol PP dan Wilayatul Hisbah yang ada di Kota Banda Aceh belum menunjukan kinerja yang baik.

Ada lagi tanggapan masyarakat terhadap kinerja personel PPNS dari Satpol PP dan Wilayatul Hisbah di Provinsi Aceh, yakni mereka beranggapan PPNS cenderung tebang pilih ketika yang melakukan penangkapan terhadap pelanggaran dan berlawanan dengan kebijakan pemerintah daerah, di mana salah satu contoh seorang oknum TNI ataupun Polisi serta pejabat politik dan penguasa di daerah, yang jelasjelas melakukan pelanggaran Qanun 11 Tahun 2002, Qanun 12 Tahun 2003, Qanun 13 Tahun 2003, dan Qanun 14 Tahun 2003, namun tidak tersentuh oleh penertiban. Lain halnya apabila yang melakukan pelanggaran adalah masyarakat biasa, maka oknum PPNS segera melakukan tindakan tegas. Artinya, unsur keadilan disini tidak menjadi fokus perhatian dari para personel PPNS. Seharusnya, setiap orang, apapun jabatan dan kedudukannya berdiri sejajar dimuka hukum, sehingga siapapun yang melakukan pelanggaran, wajib ditindak tegas tanpa pandang bulu.

Kemudian, khususnya untuk oknum Polisi Wilayatul Hisbah, masyarakat menilai perilakunya terlalu arogan ketika melakukan operasi, contohnya ketika kaum muslimah berpakaian gamis, yaitu memakai baju terusan sampai ke lutut tetapi memakai pakaian celana dengan berbahan jeans tetap ditertibkan, padahal celana jeans-nya hampir tertutup baju gamis. Dalam hal ini, Polisi Wilayatul Hisbah dianggap kurang memperhatikan aspek hak asasi manusia yang seharusnya di junjung setinggitingginya, karena memakai celana jeans merupakan hak asasi seseorang untuk memakainya. Masyarakat menginginkan keduanya berjalan searah, di mana penegakan Syariat Islam tetap berjalan dan hak asasi manusia juga di junjung tinggi.

Ditinjau dari aspek kelembagaan, jabatan PPNS yang terdapat di Satpol PP Provinsi Aceh, Kota Sabang dan Kabupaten Aceh Besar, keseluruhannya merupakan jabatan struktural, di mana hal ini merupakan menyebabkan kurangnya animo dan minat dari aparatur, khususnya yang berada di unit Satpol PP sebagai penegak kebijakan pemerintah daerah. Dengan jabatan struktural ini, PPNS tidak dapat berkembang dari sisi karier dan prestasinya, dan hanya mengikuti aturan yang ada tentang kenaikan jabatan dan pangkat berdasarkan aturan jenjang kepangkatan dari Kementerian PAN \& RB dan Badan Kepegawaian Negara, yang artinya sama dengan jabatan fungsional umum.

Kemudian, dari fakta lapangan juga diketahui bahwa pimpinan Satpol PP Provinsi Aceh, Kota Sabang dan Kabupaten Aceh Besar belum otomatis menyandang jabatan sebagai PPNS. Hal ini penting untuk diketahui dan dibahas, karena dengan keberadaan seorang Pimpinan atau Kepala Satuan Polisi Pamong Praja yang merangkap sebagai PPNS, maka diharapkan pelaksanaan penegakan Perda akan berjalan lebih efektif dan efesien. Namun hal itu tidak ditemui di lokasi kajian, di mana akibatnya pelaksanaan penegakan Perda dan Qanun belum optimal. Figur pimpinan sangat berpengaruh, terutama ketika PPNS tersebut ada di lingkungan birokrasi. Apabila inisiatif penegakan Perda dan Qanun berasal dari pimpinan Satpol PP, akan sangat memudahkan personelnya untuk melakukannya dengan maksimal.

Terkait pembentukan sekretariat di Unit Satpol PP, ternyata dari hasil identifikasi di lapangan, menunjukkan bahwa di Provinsi Aceh, Kota Sabang dan Kabupaten Aceh Besar belum terbentuk Sekretariat PPNS di Unit Satpol PP. Hal inilah salah satu alasan bahwa pelaksanaan penegakan Perda di Provinsi Aceh, Kota Sabang dan Kabupaten Aceh Besar belum berlangsung efektif dan efesien, oleh karena PPNS yang ada menyebar dan melekat pada dinas-dinas yang ada di Pemerintah Daerah Provinsi Aceh, Pemerintah Kota Sabang dan Pemerintah Daerah Kabupaten Aceh Besar, yang dituntut berkoordinasi dengan PPNS Satpol PP dan Kepolisian selaku koordinator dan pengawas PPNS.

Pola kerjasama dan koordinasi Polisi PP dan Wilayatul Hisbah Provinsi Aceh dengan intansi terkait di daerah, telah dilakukan melalui MoU (Nota Kesepahaman) berupa kerjasama dan koordinasi dengan kepolisian daerah dalam bidang bina mitra dengan Polda dan TNI Angkatan Laut, dari mulai 18 Maret 2008 sampai dengan sekarang, kemudian dengan Kejaksaan, Kehakiman dalam bidang audiensi sampai sekarang, Perguruan Tinggi Negeri, IAIN dan Perguruan Tinggi Swasta UNSYIAH dari Tahun 2011. Selanjutnya, kerjasama juga dilakukan dengan lembaga luar negeri dalam bidang partnership dari tahun 2008 sampai dengan tahun 2009, dan juga kerjasama dilakukan dengan lembaga-lembaga lainnya seperti Biro Hukum Setda Aceh dan Dinas Sosial dari tahun 2010 sampai sekarang ini. 


\section{SIMPULAN}

Dari uraian di atas, dapat disimpulkan bahwa: (1) Kelembagaan PPNS di Provinsi Aceh, Kota Sabang dan Kabupaten Aceh Besar berbentuk jabatan struktural, Kepala Satpol PP belum menjadi PPNS, serta pembentukan Sekretariat PPNS di Satpol PP pada umumnya belum dilaksanakan; (2) Pelaksanaan Penyidikan PPNS masih belum optimal; (3) Sebagian besar pelanggaran Qanun, penyelesaian kasusnya bersifat pembinaan di tempat maupun pembinaan di kantor, dan tindaklanjut kasus sampai pada lembaga peradilan hanya pada beberapa kasus saja; (4) Kerjasama dan koordinasi telah dilakukan pihak Kepolisian selaku Korwas PPNS, khususnya di Kota Sabang kerjasama dan koordinasi dilakukan dengan Polda dan TNI Angkatan Laut dalam bidang bina mitra, dan dengan Kejaksaan, Kehakiman, Perguruan Tinggi, dan unit kerja internal; dan (5) Sumber daya manusia personel PPNS masih minim kuantitas dan kualitasnya, di mana pada umumnya didominasi kaum pria serta tingkat pendidikan terbesar berlatar belakang pendidikan Sarjana (S1), dan dari usia PPNS terbanyak pada usia 36 tahun sampai dengan 45 tahun.

Oleh karena itu, disarankan untuk: (1) Dilakukan perubahan sistem jabatan struktural yang melekat pada PPNS, menjadi jabatan fungsional PPNS sesuai dengan kelompok 101 rumpun jabatan fungsional penyidikan dan detektif; (2) keBeradaan PPNS perlu diatur pada tingkatan Peraturan Pemerintah, mengingat PPNS tidak saja berada pada unit Satpol PP, tetapi juga berada pada instansi vertikal lainnya; (3) Mendesak Kementerian Hukum dan Hak azasi Manusia untuk segera mengeluarkan dan menerbitkan Surat Keputusan Penyidikan (Skep) dan Kartu Tanda Penyidikan (KTP) yang baru, agar status personel yang telah menjadi pendidikan dan pelatihan jelas; (4) Mendorong calon PPNS daerah yang guna mengikuti pendidikan dan pelatihan PPNS, khususnya bagi calon-calon muda dan berjenis kelamin perempuan serta berpendidikan Pasca Sarjana; dan (5) Membantu daerah dari aspek pendanaan.

\section{DAFTAR PUSTAKA}

Garna, Judistira K. 2000. Metode Penelitian Sosial: Penelitian Dalam Ilmu Pemerintahan, Bandung: Primako Akademika.

Hamdi, Mukhlis. 1999. Desentralisasi dan Pembangunan Daerah. Makalah pada Lokakarya Pengembangan Kemampuan Pemda Tingkat II Jakarta.

Ndraha, Taliziduhu. 1997. Metodologi Ilmu Pemerintahan, Jakarta: Rineka Cipta.

Rasyid, M. Ryaas. 2000. Makna Pemerintahan, Jakarta: Yarsif Watampone.

Jacques, Jean Rousseau. 1986. Kontrak Sosial, Terjemahan Sumarjo, Erlangga, Jakarta.
Pamudji, S. 1985. Ekologi Administrasi Negara. Bina Aksara: Jakarta.

Suryaningrat, Bayu. 1990. Pemerintahan dan Administrasi Desa, Mekar Jaya, Bandung.

Syafiie, Inu Kencana. 1998. Manajemen Pemerintahan. Jakarta: PT. Pertija.

Syafiie, Inu Kencana. 2000. Sistem Pemerintahan Indonesia. Jakarta: Rineka Cipta.

Yayat M., Herujito. 2001. Dasar-Dasar Manajemen, Grasindo, Bogor.

Peraturan Pemerintah Nomor 6 Tahun 2010 tentang Kesatuan Polisi Pamong Praja.

Peraturan Pemerintah Nomor 58 Tahun 2010 tentang Perubahan Atas Peraturan Pemerintah Nomor 27 Tahun 1983 Tentang Pelaksanaan Kitab Undang-Undang Hukum Acara Pidana Pejabat Penyidik Pegawai Negeri Sipil.

Peraturan Menteri Dalam Negeri Nomor 66 Tahun 2011 Tentang Kode dan Data Wilayah Administrasi Pemerintahan.

Peraturan Menteri Dalam Negeri Nomor 11 Tahun 2009 Tentang Kode Etik Penyidik Pegawai Negeri Sipil Daerah.

Peraturan Pemerintah Nomor 99 Tahun 2000 jo Peraturan Pemerintah Nomor 12 Tahun 2002 tentang Kenaikan Pangkat Pegawai Negeri Sipil.

Peraturan Kepala Kepolisian Negara Republik Indonesia Nomor 6 Tahun 2010 Tentang Manajemen Penyidikan Oleh Penyidik Pegawai Negeri Sipil Penyidik Pegawai Negeri Sipil.

Surat Menteri Dalam Negeri Nomor 182.1/857/SJ tahun 2011 tentang Pembentukan Sekretariat PPNS Pada Kantor Satpol PP.

Undang-Undang Nomor 8 Tahun 1981 tentang Hukum Acara Pidana.

Undang-Undang 32 Tahun 2004 tentang Pemerintahan Daerah.

Undang-Undang Nomor 34 Tahun 2004 tentang Tentara Nasional Indonesia.

Bentuk-bentuk manajemen pengawasan http:// www.manajemenn.web.id/2011/04/bentukbentuk-pengawasan.html, diunduh tgl 12 Pebruari 2012.

Sistim Informasi Dokumen Hukum http://birohukum. gorontalofamily.org/biro-hukum.html, diunduh tanggal 14 Pebruari 2012. 